\title{
Behavioral changes in dairy cows with mastitis
}

\author{
C. Medrano-Galarza, ${ }^{\star}$ J. Gibbons, $\dagger^{1}$ S. Wagner, $\neq$ A. M. de Passillé, $\dagger$ and J. Rushen $†$ \\ ${ }^{*}$ Applied Animal Behavior and Animal Welfare Programme, The University of Edinburgh, Easter Bush Veterinary Centre, \\ Roslin EH25 9RG, United Kingdom \\ †Agriculture and Agri-Food Canada, PO Box 1000, Agassiz, British Columbia, V0M 1A0, Canada \\ fDepartment of Animal Science, PO Box 6050, North Dakota State University, Fargo 58108
}

\begin{abstract}
Mastitis is a frequent and painful disease in dairy cows. However, pain detection and alleviation in mastitic cows has been overlooked. The objectives of this study were to measure behavioral changes in dairy cows with clinical mastitis and to investigate the effect of intramammary infusion of an antibiotic on lying behavior and behavior during milking. In experiment 1, 42 lactating cows were used: 14 mastitic cows and 28 control cows. Mastitic and control cows were subjected to an evaluation of pain responses on $\mathrm{d} 1$ (mastitis detection day), and 2, 3, and $7 \mathrm{~d}$ after the last antibiotic treatment (d 10+). The antibiotic treatment was administered to mastitic cows twice a day, starting on d 1, for at least 3 consecutive days. Behavioral changes were evaluated by measuring lying behavior, reactivity during milking (stepping, lifting, and kicking), weight distribution, and hock-to-hock distance. Overall, mastitic cows spent less time lying down on d 2 compared with control cows. The percentage of time lying on the mastitic quarter side did not differ significantly between mastitic and control cows. No differences were observed between control and mastitic cows on the number of steps per $24 \mathrm{~h}$ on each day. Restless behavior during milking did not differ between treatments. Restless behaviors differed significantly within mastitic cows between days. Frequency of kicks per minute was higher on d 1 compared with d 2, frequency of lifts was higher on d 1 and 2 compared with d 10+, and frequency of steps was higher on d 2 compared with d 10+. The variability of weight that mastitic cows applied to the leg on the mastitic quarter side was higher on $\mathrm{d} 1$ than on $\mathrm{d} 10+$. For control cows, the variability in weight applied to the homologous leg of the mastitic quarter side leg was higher on d 1 compared with $\mathrm{d} 2$ and 3 . The hockto-hock distance did not differ between treatments. Mild clinical mastitis might not cause sufficient pain
\end{abstract}

Received December 8, 2011.

Accepted August 9, 2012.

${ }^{1}$ Corresponding author: jenny.gibbons@hotmail.co.uk to observe marked changes in behaviors. However, cows showed differences in lying time and reactivity during milking and slight differences in the laterality of lying. To further develop methodologies for assessing pain in mastitic cows, it is worth applying the methodologies used in this study to cows with moderate to severe mastitis, followed by their validation using analgesic treatment, to ensure that any change is a pain-specific behavior rather than a simple reflex. In experiment 2, no effect of intramammary infusion of the antibiotic was observed on lying behavior or behavior during milking. Cows with mild clinical mastitis present behavioral changes in lying behavior and at milking time, which could be associated with discomfort.

Key words: cattle, mastitis, behavior, pain assessment

\section{INTRODUCTION}

Mastitis is prevalent in modern dairy herds and can have detrimental effects on productivity and animal welfare. Cows with mastitis often receive little to no treatment for pain, and inadequate analgesic treatment of cows with mastitis is a major risk that could compromise cow welfare (EFSA, 2011). To date, the majority of research has focused on evaluating the effects of analgesic therapy on cows with experimentally induced mastitis (Fitzpatrick et al., 1999, 2011; Wagner and Apley, 2004). Siivonen et al. (2011) found that cows with experimentally induced mastitis spent less time lying down and less time lying on the mastitic side after the induction of mastitis compared with the day before induction. However, very few studies have evaluated the effects of pain attributable to naturally occurring mastitis on behavior. Kemp et al. (2008) report that cows with mild and moderate mastitis had a wider hock-to-hock distance than healthy cows. Although not specifically dealing with mastitis, Hassall et al. (1993) and Rousing at al. (2004) found that cows with lesions on the teat were more restless on their feet while being milked.

An assessment of different behavioral measures may be necessary to detect pain associated with mastitis. 
Table 1. Ethogram of restless behaviors recorded during milking

\begin{tabular}{ll}
\hline Behavior & Definition \\
\hline Step & The hoof is lifted off the ground without going higher than the upper part of the dew-claw. \\
Lift & The hoof is lifted off the ground higher than the upper part of the dew-claw but lower than the middle point between the dew- \\
Kick & claw and the point of the hock. \\
\hline
\end{tabular}

Measures that have been used to assess other painful conditions, such as lameness, include time spent lying down (Chapinal et al., 2010a), weight distribution when standing (Neveux et al., 2006), and weight shifting between legs (Rushen et al., 2007). These measures may be useful to assess the pain caused by mastitis. Thus, the objective of this study was to measure behavioral changes in cows with naturally occurring clinical mastitis that might be related with pain. The evaluation of these changes was based on a combination of objective, quantitative measures of lying behavior, restless behaviors during milking, weight distribution, and interhock distance.

\section{MATERIALS AND METHODS}

\section{Animals and Housing}

Procedures were approved by the local Institutional Animal Care Committee (monitored by the Canadian Council on Animal Care, Ottawa, ON, Canada). Lactating Holstein cows were housed in sand-bedded freestalls $(2.4 \mathrm{~m}$ long $\times 1.18 \mathrm{~m}$ wide $\times 0.40 \mathrm{~m}$ deep $)$. Each cow had access to 1 stall per cow at the University of British Columbia's Dairy Education and Research Centre (Agassiz, BC, Canada). Cows were fed a TMR twice daily $(45.5 \%$ concentrate and $54.5 \%$ forage on a DM basis). Water was supplied ad libitum. The cows were milked twice daily (0500 and $1500 \mathrm{~h}$ ). All cows had a BCS $>2$ and a sound gait, with gait scores assessed using the 5-point scale from Flower and Weary (2006).

\section{General Procedures and Measures}

Lying and Activity. IceTag data loggers (dimensions: approximately $6 \mathrm{~mm}$ high $\times 60 \mathrm{~mm}$ wide $\times 30$ deep; IceRobotics Ltd., Edinburgh, UK) were attached to the hind legs above the fetlock and programmed to record cow activity (step count), with a sampling rate of 16 readings per second (Chapinal et al., 2010b; Gibbons et al., 2012). Hobo Pendant G data loggers (dimensions: approximately $33 \mathrm{~mm}$ high $\times 60 \mathrm{~mm}$ wide $\times 25$ deep; Onset Computer Corporation, Pocasset, MA) were attached with Vet Wrap (Co-Flex; Andover Coated Products Inc., Salisbury, MA) at the level of the middle part of the metatarsus. They were programmed to record lying behavior by using a logging interval of 1 reading per minute and gravitational forces as a unit (Ito et al., 2009; Ledgerwood et al., 2010).

Milking Behavior. The cows were milked in a Boumatic double-12 parallel parlor. Milking time was considered the time from when the cow entered her milking stall until completion of postdip of the last teat (Cavallina et al., 2006). The behaviors of the cows during milking were recorded using a Panasonic SDR-H85PC video camera (Panasonic Shikoku ElectronicsWest Java, Indonesia). The camera was held by the observer or positioned on a tripod at a height of approximately $1.5 \mathrm{~m}$. The observer and tripod were standing approximately $1.3 \mathrm{~m}$ from the rear of the cow so the view of the udder, hind legs, claws, and the floor on which the cow was standing during milking were not obstructed. Observers scored step, kick, and lift behaviors from the videos taken by using CowLog Software (Hänninen and Pastell, 2009). Detailed descriptions of the observed behaviors are shown in Table 1. The observers were blind to treatment. Spearman rank correlation measures of intraobserver and interobserver repeatability ranged from 0.92 to 0.99 and 0.86 to 1.00 respectively.

Weight Distribution. Weight distribution among the cow's 4 legs while standing on a force plate scale (composed of 4 independent recording units, 1 per leg: $12 \mathrm{~cm}$ high $\times 59 \mathrm{~cm}$ wide $\times 99 \mathrm{~cm}$ long; Pacific Industrial Scale Co. Ltd., Richmond, BC, Canada) was recorded for 5 min using the method described by Neveux et al. (2006) and Chapinal et al. (2009, 2010a,b). It was not possible to habituate the cows to the scale during our study, unlike previous studies (Chapinal et al., 2009, 2010a,b; Pastell et al., 2010), because of the uncertainty of when a cow would be diagnosed as mastitic. However, to avoid the development of negative associations related to the scale, cows were rewarded with food on the scale once they were standing calm and their head restrained.

Hock-to-Hock Distance. The distance was measured by using a retractable measuring tape, and the calcaneal tuberosities (point of hock) of both hind legs were used as the reference points as described by Kemp et al. (2008). This procedure was done while the cows were standing on the force plate scale. 


\section{Specific Experimental Procedures}

Experiment 1. The aim was to evaluate behavioral changes by measuring lying behavior, which included total lying time and laterality of lying (time spent lying on the right or left side), activity (steps), weight distribution, restless milking behavior, and hock-to-hock distances for mastitic and control cows (treatments).

Fourteen cows with clinical mastitis (mean \pm SD; parity $=3.92 \pm 1.77 ; \mathrm{DIM}=185.14 \pm 104.06)$ and 28 healthy nonmastitic controls (mean \pm SD; parity $=$ $3.75 \pm 1.50 ; \mathrm{DIM}=173.29 \pm 87.66)$ were used for this experiment. Each mastitic cow was matched on parity and DIM with 2 control cows (making up a group) to allow for the possibility that control cows would be lost because of illness, high SCC, lameness, or difficulty in using the force plate scale.

Mastitis was detected before milking by the milker using visual inspection for abnormalities in the milk or changes in udder appearance. In 12 cases, clinical mastitis was diagnosed as mild mastitis by the presence of clots in the milk, and in 2 cases, it was diagnosed as moderate mastitis by the presence of clots and a swollen and warm infected quarter following the criteria described by Hogan et al. (1989) and Eckersall et al. (2001). A milk sample from the mastitic quarter was taken for bacteriological culture on the day of detection and analyzed by the Animal Health Centre Accredited Laboratory (Ministry of Agriculture, Abbotsford, BC, Canada). Enterococcus faecium, Klebsiella oxytoca, and Escherichia coli were isolated in 5, 3, and 2 mastitic cows, respectively; no bacteria were detected in 4 mastitic cows. Four cows had mastitis on a back quarter (3 on the right and 1 on the left) and 10 had mastitis on a front quarter (3 on the right and 7 on the left). Selected control cows had historical SCC of 27,000 $\pm 30,000$ cells $/ \mathrm{mL}$ (mean $\pm \mathrm{SD}$ ) for the previous 3 mo, and SCC of $63,643 \pm 76,177$ cells $/ \mathrm{mL}$ (mean $\pm \mathrm{SD}$ ) on the day of detection (d 1).

For ethical reasons, treatment for mastitis was not withheld. Mastitic cows received an intramammary infusion of antibiotic (Cefa-Lak; Wyeth Animal Health, Division of Wyeth Canada, Guelph, ON, Canada) twice daily for 3 consecutive days, starting on the mastitis detection day. This procedure was carried out by the milkers as stated in the mastitic treatment protocol indicated by the manager at the University of British Columbia's Dairy Education and Research Centre. Control cows did not receive this intramammary infusion (see experiment 2). Milk samples were analyzed for SCC for control cows at the beginning of the trial and for both control and mastitic cows at the end to confirm the absence of mastitis (Pacific Milk Analysis Laboratory, Chilliwack, BC, Canada). To classify both mastitic and control cows as healthy at the end of the trial, SCC had to be less than 250,000 cells/mL [(mean \pm SD) $179,800 \pm 196,400$ and $58,460 \pm 80,320$, respectively; Smith, 2009; Viguier et al., 2009].

Cows were detected with mastitis during the morning or afternoon milking, the time of mastitis detection was recorded, and 24-h periods were calculated from this detection time. Each mastitic cow and her 2 controls were evaluated for behavioral responses on $\mathrm{d} 1,2,3$, and $10+$ (a minimum of $7 \mathrm{~d}$ after the last antibiotic treatment: mean $\pm \mathrm{SD}=7.93 \mathrm{~d} \pm 0.62)$ of the trial. Day 1, 2, and 3 were known as mastitis treatment days, when the cows received intramammary antibiotic treatment. Day 10+ was considered a baseline, when the mastitic cows were mastitis free. The mean $( \pm \mathrm{SD})$ duration of the trial for each group was $10.35 \mathrm{~d}$ $( \pm 0.49)$. Cows that were detected with mastitis during the morning milking had data loggers attached midmorning, and cows detected in the afternoon milking had data loggers attached during the following morning milking. A Hobo data logger was attached to 1 hind leg, balancing for right and left, and IceTag data loggers were attached to both hind legs of the mastitic and control cows on $\mathrm{d} 1$.

Experiment 2. Because we could not control for effects of the antibiotic treatment used in experiment 1 , the aim was to evaluate the effect of intramammary infusion of antibiotic on total lying time, laterality of lying, and restless behavior in healthy nonmastitic cows. Sixteen healthy midlactating Holstein cows were randomly split into 2 treatment groups: an antibiotictreated group $(\mathrm{n}=8)$ and a control group $(\mathrm{n}=8)$. The groups were matched for DIM, parity, SCC, and projected milk yield $[\mathbf{P M Y}$ (in liters; mean $\pm \mathrm{SD}$ ); antibiotic group: $\mathrm{DIM}=141.2 \pm 34.35$; parity $=2 \pm$ 1.069; $\mathrm{SCC}=53.62 \pm 33.85 ; \mathrm{PMY}=12,446 \pm 435.73$; control group: DIM $=151.25 \pm 30.17 \mathrm{~d}$; parity $=2 \pm$ 1.069; $\mathrm{SCC}=34.57 \pm 11.75 ; \mathrm{PMY}=11,701 \pm 1706.9$ L]. The treated group received an intramammary infusion of antibiotic (Cefa-Lak) for 4 consecutive milkings. Treated quarters were balanced between treatments and only the left or right back quarters were used. Each cow was in the trial for $16 \mathrm{~d}$ (starting on $\mathrm{d}-6$ and ending on d 9). The trial was split into 4 periods as follows: (1) habituation: 1 Hobo data logger was attached to each hind leg (to avoid losing data) on $\mathrm{d}-6$, and the cows were given a 24-h habituation period; (2) prebaseline: $\mathrm{d}-5$ to -1 were used to collect baseline lying behavior data before the antibiotic treatment; (3) treatment: the antibiotic treatment was administered to the antibiotictreated cows on d 0 and 1; and (4) postbaseline: from d 5 to 9 , data were collected after treatment. Restless behavior during milking was recorded on $\mathrm{d}-2,-1,0$, 1 , and 9 . 


\section{Data Analysis: Experiment 1}

In experiment 1 , data from 4 of the 28 control cows was discarded because of illness (lameness and displaced abomasum) or high SCC $(>250,000$ cell $/ \mathrm{mL})$. In the remaining 10 pairs of control cows, 1 control cow was selected randomly. Therefore, only 1 control cow matched to the mastitic cows was used for subsequent analysis. Data on all measures from 1 mastic cow on d 10+ was discarded because of high SCC (SCC = 817,000 cells $/ \mathrm{mL}$ ). Lying laterality data of 1 mastitic cow was discarded for $\mathrm{d} 2,3$, and $10+$ because of a displaced Hobo logger. Additionally, 1 mastitic cow and the paired control cow did not have data on weight distribution and hock-to-hock distance because of unforeseen circumstances.

Lying and Activity, and Behaviors During Milking. The following variables were calculated on a 24-h basis from Hobo and IceTag data: total lying time and percentage of total time lying on the mastitic side (which corresponded to total time lying on the homologous side in control cows) and the number of steps walked, respectively. Because of the timing of attachment of the data loggers, cows detected with mastitis during the afternoon milking had $12 \mathrm{~h}$ less lying and activity data compared with cows detected in the morning milking; therefore, $\mathrm{d} 1$ was not analyzed for these behaviors. Frequencies of steps, lifts, and kicks per minute were calculated for each milking to allow comparisons between milkings of different lengths.

Weight Distribution. The percentage of weight $(\mathrm{kg})$ applied to the leg on the mastitic side and the SD of weight $(\mathrm{kg})$ applied to that leg, which is a measure used to assess the variability of weight applied to the legs (weight shifting) (Rushen et al., 2007), were used as variables to assess changes in weight distribution between mastitic and control cows.

Hock-to-Hock Distance. An average between 2 measures of hock-to-hock distance taken per cow was calculated for each day.

\section{Data Analysis: Experiment 2}

In experiment 2, lying behavior variables included total lying time and percentage of total time lying on the treated quarter. An average was calculated for the prebaseline ( $\mathrm{d}-5$ to -1$)$ and postbaseline ( 5 to 9 ). Day 0 and 1 were considered treatment days. For restless behaviors during milking, the frequencies of step, lift, and kick behaviors per minute were calculated for $\mathrm{d}-2$ and -1 (prebaseline); $\mathrm{d} 0$ and 1 (treatment days); and $\mathrm{d} 9$ (postbaseline) for the treated and control cows.

\section{Statistical Analysis}

All descriptive analysis was performed in Excel, and statistical analyses were performed with SAS (version 9.2; SAS Institute, 2003). All data were checked for normality and homogeneity of variance using the Shapiro-Wilk test and Bartlett's test, respectively. Because of the nonnormality of all data apart from the SD of weight that was normally distributed, data were analyzed using the Wilcoxon sign rank test and Student's paired $t$-test, respectively. We reported the median, 25th percentile (P25), and 75th percentile (P75) for all data variables apart from the SD of weight, for which the mean and SD are reported. For experiment 1, the differences between days $(\mathrm{d} 1,2,3,10+)$ for mastitic and control cows, and differences between treatments (control vs. mastitic) within days were calculated for all variables. In experiment 2 , the differences between antibiotic-treated and control cows within the prebaseline, treatment, and postbaseline periods were calculated for lying behavior variables and restless behaviors during milking.

\section{RESULTS}

\section{Experiment 1}

Lying and Activity. Mastitic cows spent significantly less time lying down on d 2 than did control cows (Table 2). The same trend was apparent on d 10+ but was not significant. No differences were observed between days for each treatment.

The percentage of time lying on the mastitic quarter side did not differ significantly $(P>0.10)$ between control and mastitic cows on d 2, 3, and 10+, and no differences were observed between days for each treatment. However, mastitic cows showed a greater degree of laterality than did control cows. Figure 1 shows the mean percentage of time that control cows spent lying on the right side for the length of the trial $(10.35 \pm 0.49$ d). On average, for a 24 -h period, control cows spent $46.95 \pm 9.46 \%$ (mean $\pm \mathrm{SD}$ ) of the time lying on the right side (minimum, 28.34\%; maximum, $69.27 \%$ ), but no cows spent more than $75 \%$ of the time lying on only 1 side (Figure 1). In contrast, mastitic cows spent 43.21 $\pm 23.95 \%$ (mean $\pm \mathrm{SD}$ ) of the time lying on the mastitic side, but 6 of the mastitic cows spent more than $75 \%$ lying on only 1 side ( 4 on the nonmastitic side and 2 on the mastitic side; Figure 2). From the 4 mastitic cows that spent less than $30 \%$ of their time lying on the mastitic side, 3 of them had no bacteria isolated in their milk samples and 1 had K. oxytoca. The 2 mastitic cows that spent more than $60 \%$ of their time lying on the mastitic side had E. faecium. 
Table 2. Differences in the total lying time $(\mathrm{min} / 24 \mathrm{~h})$ between control and mastitic cows by days and between days for each treatment (control and mastitic cows)

\begin{tabular}{|c|c|c|c|c|c|}
\hline Item $^{1}$ & \multicolumn{2}{|r|}{ Control cows } & \multicolumn{2}{|r|}{ Mastitic cows } & $P$-value \\
\hline d 2 & 14 & $742.5(648.0-841.0)$ & 14 & $707.5(562.8-809.0)$ & 0.04 \\
\hline d 3 & 14 & $699.0(656.0-803.0)$ & 14 & $740.5(559.8-790.3)$ & 0.26 \\
\hline $\mathrm{d}+10$ & 14 & $771.0(667.0-839.0)$ & 13 & $654.0(598.0-790.0)$ & 0.07 \\
\hline \multicolumn{6}{|c|}{$P$-value, difference between days } \\
\hline $\mathrm{d}+10-\mathrm{d} 3$ & & 0.17 & & 0.89 & \\
\hline
\end{tabular}

${ }^{1} \mathrm{~d} 2=$ first day after mastitis detection; $\mathrm{d} 3=$ second day after mastitis detection; $\mathrm{d}+10=$ minimum of $7 \mathrm{~d}$ after last antibiotic treatment. ${ }^{2} \mathrm{P} 25=25$ th percentile; $\mathrm{P} 75=75$ th percentile.

No differences were observed between control and mastitic cows on the number of steps per $24 \mathrm{~h}$ on each day $(P>0.10)$. However, mastitic cows took a significantly higher number of steps on d 3 (P25-median-P75: 1,449-1,868-2,017 steps), compared with d 10+ (1,2931,621-2,054 steps; $P=0.05)$. This difference was not found among control cows (d $3=1,549-1,657-1,830$ steps; $\mathrm{d}+10=1,379-1,500-1749$ steps; $P>0.10)$. No other differences between days were significant $(P>$ $0.10)$.

Behaviors at Milking Parlor. No differences were observed between control and mastitic cows on the frequency of steps, lifts, and kicks per minute during milking on any day $(P>0.10$ for all measures; Table 3). Nonetheless, significant differences were found between days for mastitic cows. Mastitic cows had a higher frequency of kicks per minute on d 1 compared with $\mathrm{d} 2(P<0.01)$, a higher frequency of lifts on $\mathrm{d}$ 1 and 2 compared with d $10+(P<0.01$ and $P<$ 0.001 , respectively), and a higher frequency of steps on d 2 compared with d $10+(P<0.05)$. Mastitic cows also tended to have a higher frequency of steps on $\mathrm{d} 1$ compared with d $2(P=0.07)$ and a higher frequency of lifts on d 3 compared with d $10+(P=0.06)$, but these were not significant. No differences were observed between days for control cows $(P>0.1)$.

Weight Distribution. No differences were observed between control and mastitic cows on the SD of weight and the percentage of weight applied to the leg on the mastitic quarter side on each day (Figure 3 and Table 4). For mastitic cows, a significant difference in the SD of weight applied to the legs was found between $\mathrm{d} 1$ and $10+(P<0.05)$. For control cows, the SD of weight on d 1 differed significantly from those on d $2(P<0.01)$

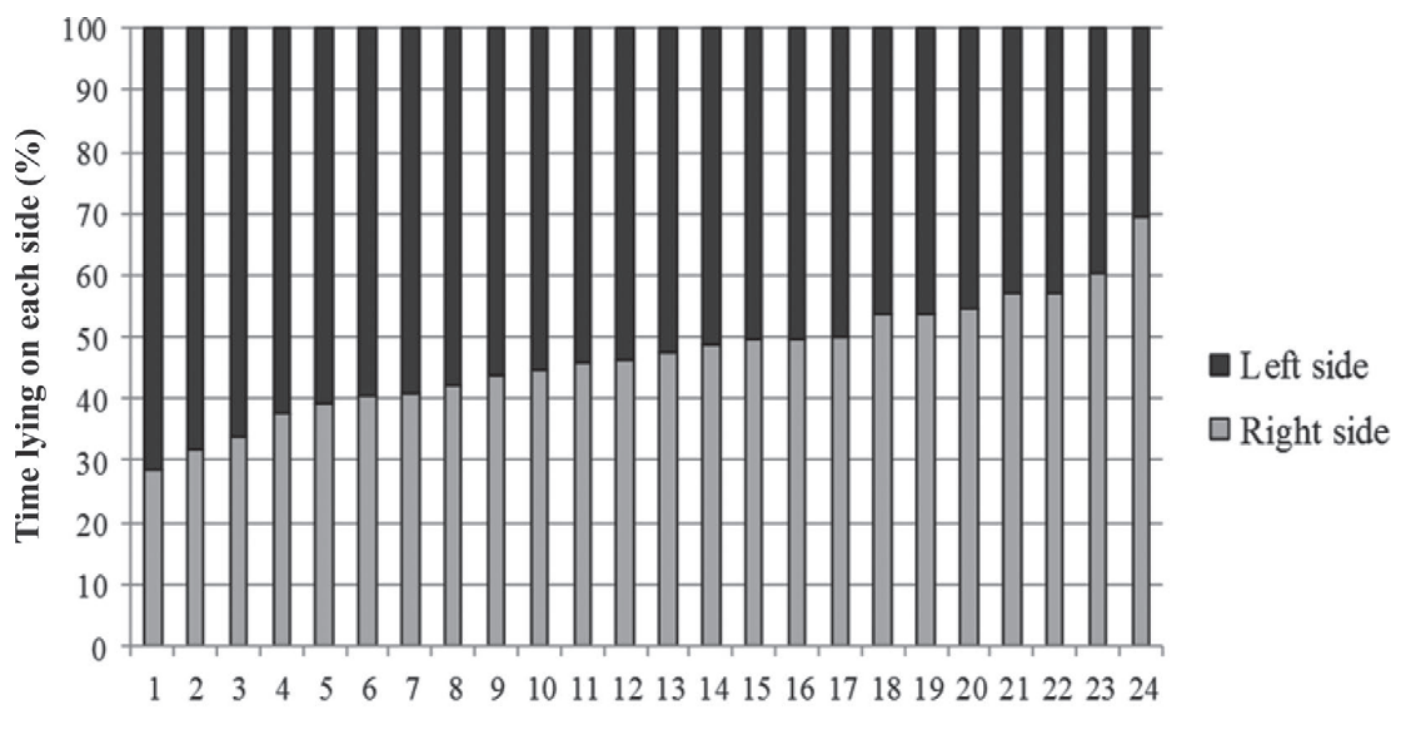

Individual cows

Figure 1. Distribution of the mean percentage of time that control cows $(\mathrm{n}=24)$ spent lying on each side (right vs. left) for a total of $10 \mathrm{~d}$. 


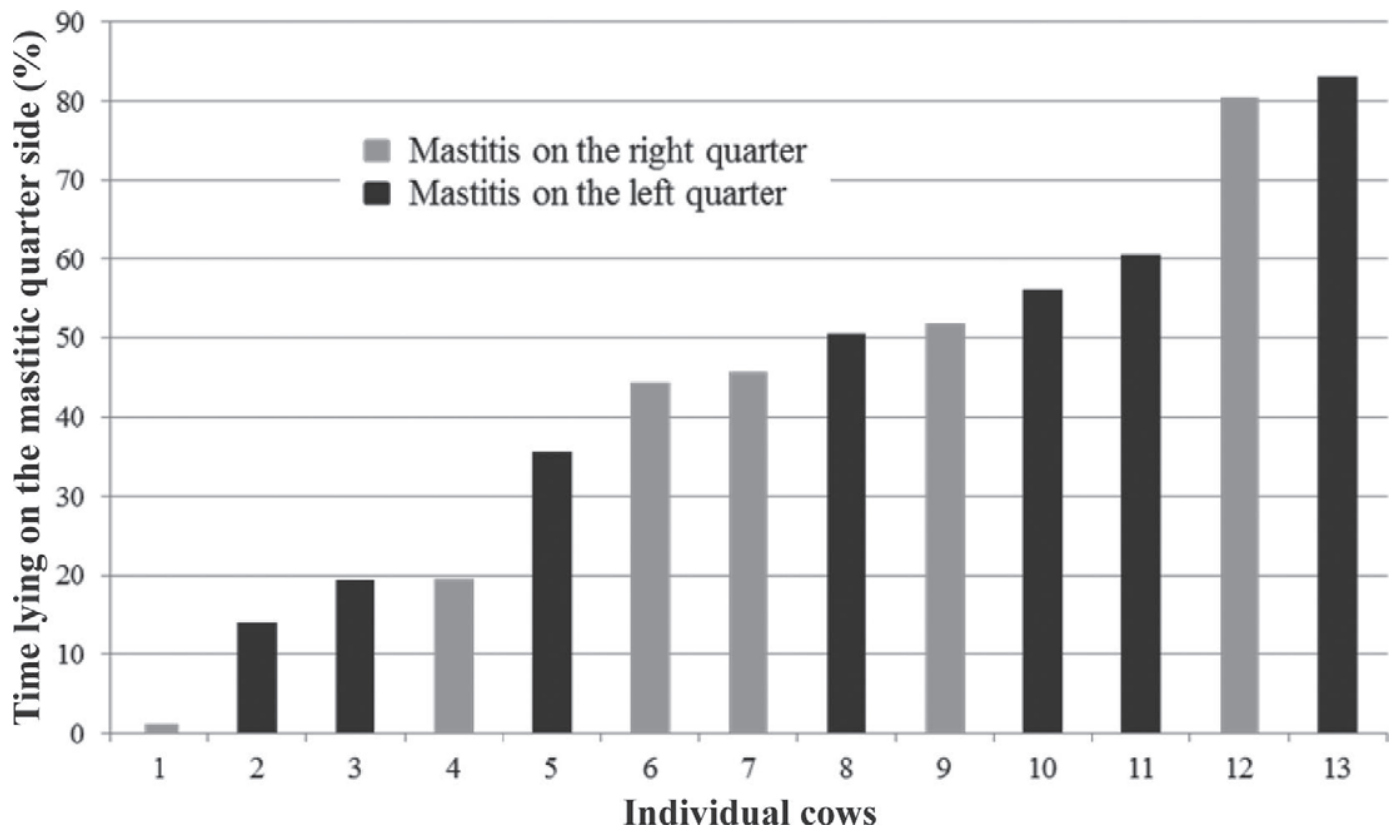

Figure 2. Mean percentage of time that mastitic cows $(\mathrm{n}=13)$ spent lying on the mastitic quarter side during $\mathrm{d} 2$ and 3.

and d $3(P<0.01)$. Between the other days, no differences were observed for either treatment $(P>0.10)$.

Hock-to-Hock Distance. No differences $(P>0.10)$ were observed in the hock-to-hock distance between control cows $(\mathrm{d} 1=27.5-29.0-30.0 \mathrm{~cm} ; \mathrm{d} 2=27.0$ $29.5-32.5 \mathrm{~cm} ; \mathrm{d} 3=27.5-29.0-32.0 \mathrm{~cm} ; \mathrm{d}+10=25.7-$ 28.5-30.2 cm) and mastitic cows (d $1=23.0-27.0-32.5$ $\mathrm{cm}$; d $2=22.4-27.0-32.5 \mathrm{~cm}$; d $3=24.0-26.0-31.0 \mathrm{~cm}$; $\mathrm{d}+10=23.9-26.0-31.5)$ (P25-median-P75). Similarly, no differences were observed between days for each treatment $(P>0.10)$.

\section{Experiment 2}

No differences were observed between antibiotictreated and control cows on total lying time and percentage of time lying on the treated quarter side for any period $(P>0.10)$. Additionally, no differences were

Table 3. Frequency of steps, lifts, and kicks per minute for control and mastitic cows

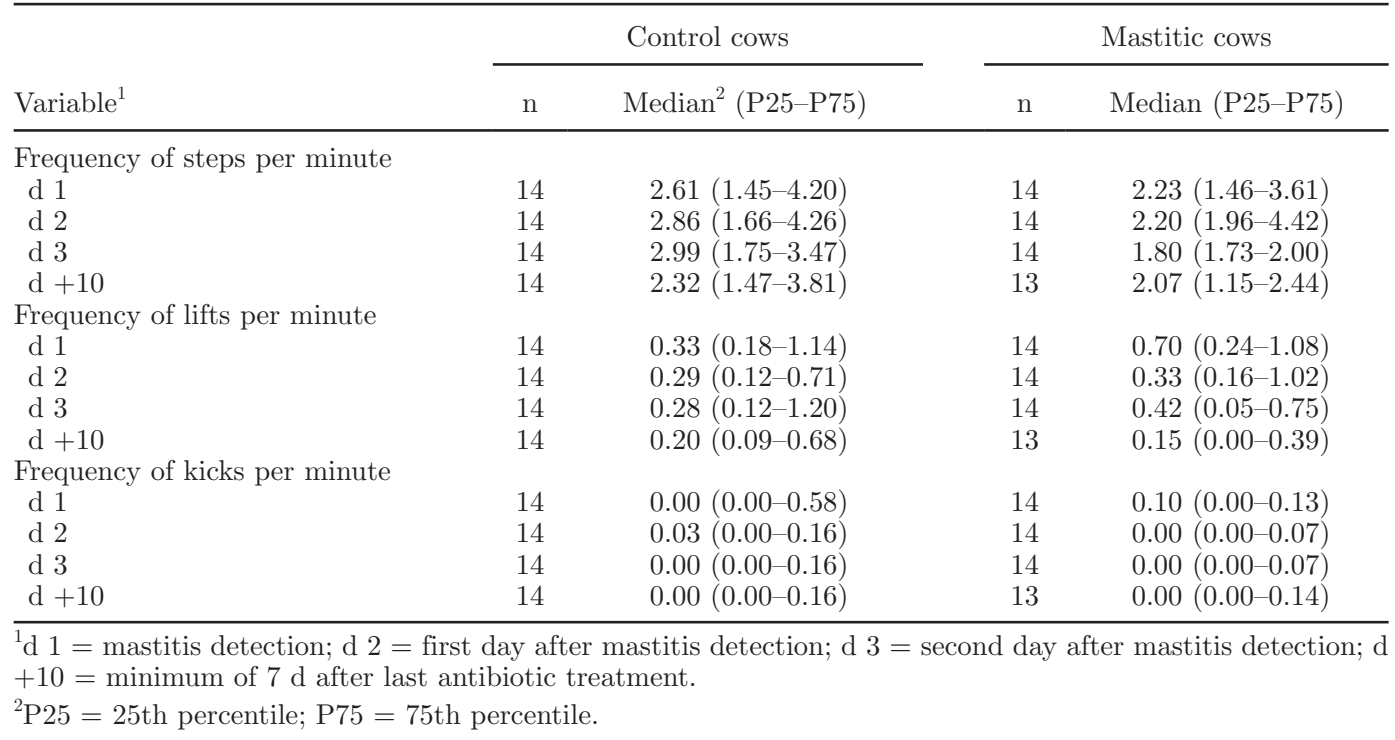


Table 4. Differences in the percentage (\%) of weight applied to the leg on the mastitic quarter side between mastitic and control cows for each day

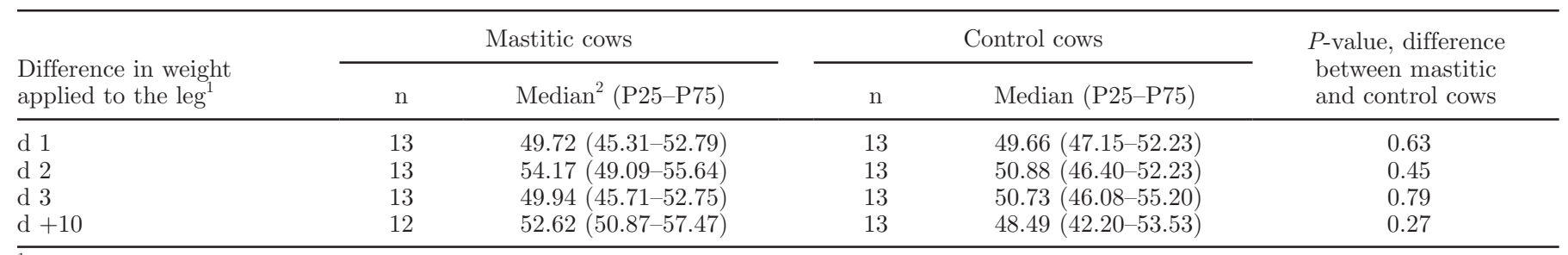

${ }^{1} \mathrm{~d} 1=$ mastitis detection; $\mathrm{d} 2=$ first day after mastitis detection; $\mathrm{d} 3=$ second day after mastitis detection; $\mathrm{d}+10=$ minimum of $7 \mathrm{~d}$ after last antibiotic treatment.

${ }^{2} \mathrm{P} 25=25$ th percentile; P75 $=75$ th percentile.

observed between control and antibiotic-treated cows on the frequency of lifts and kicks per minute between $\mathrm{d}-2,-1,1,0,9(P>0.22)$. No differences were observed between control and antibiotic-treated cows on the frequency of steps per minute between $\mathrm{d}-1,1,0$ $(P>0.84)$. However, we observed a statistical trend for antibiotic-treated cows to display a higher number of steps on $\mathrm{d}-2(P=0.08)$ and $\mathrm{d} 9(P=0.08)$.

\section{DISCUSSION}

Although the pattern of results was not simple, we found evidence that mastitis resulted in decreased time spent lying down, increased preference for lying on 1 side, and increased restless behavior during milking. These behavioral effects are potential measures of the pain associated with naturally occurring mastitis and cannot be attributed to the intramammary infusion of the antibiotic received by the mastitic cows because intramammary infusion of the antibiotic did not affect lying behavior or behavior during milking in healthy nonmastitic cows. However, we found no evidence that

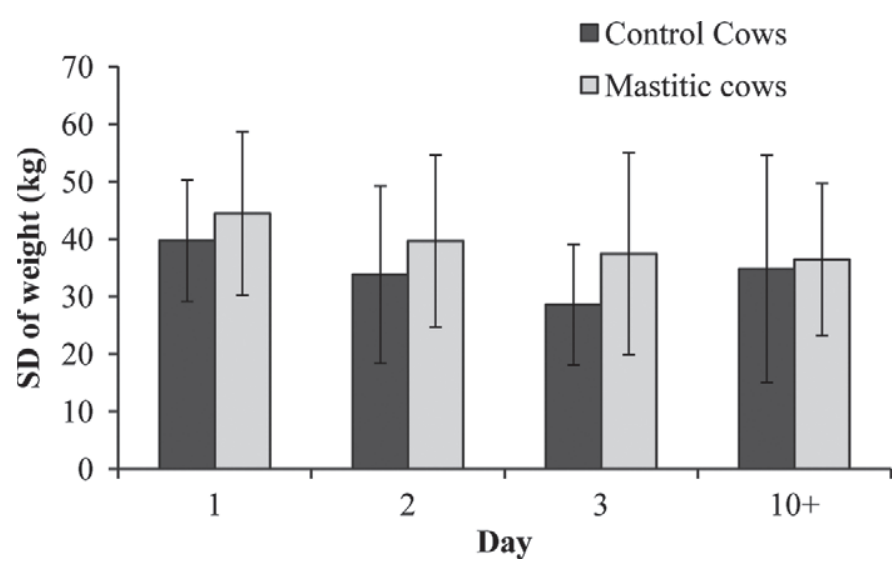

Figure 3. Mean \pm standard deviation of the standard deviation (SD) of weight applied on the leg on the mastitic quarter side (homologous leg for control cows) on each day for both treatments: control and mastitic cows. mastitis affected BW distribution or the hock-to-hock distance in dairy cows.

The evaluation of lying behavior and laterality are important measures of cow welfare and comfort (Forsberg et al., 2008; O'Driscoll et al., 2008). In experiment 1 , mastitic cows spent less time lying down on the day after mastitis detection compared with control cows. In agreement with these results, Cyples et al. (2012) reported that experimentally induced mastitic cows spent 73.3 min less lying down on the day of the challenge compared with the baseline $(P=0.005)$. Additionally, in our study mastitic cows showed an increase in activity (greater number of steps walked) during mastitic days compared with control cows and with the baseline day. Similarly, Siivonen et al. (2011), aside from finding that cows with experimentally induced mastitis tended to spend less time lying down $(P<0.07)$, also found that mastitic cows exhibited more stepping $(P=0.02)$ on the induction day than the control day $(1 \mathrm{~d}$ before induction). It is possible that mastitic cows may have a reduced motivation for lying down compared with healthy cows because of the pain experienced in the udder.

Ledgerwood et al. (2010) suggested that pronounced changes in the laterality of lying down (i.e., a preference for lying on 1 side) may indicate that cows are uncomfortable. Although no differences were observed in the percentage of time lying on the mastitic side between control and mastitic cows, mastitic cows were more extreme in their lying side preferences than was any control cow; 6 cows spent more than $70 \%$ lying on 1 side, whereas no control cows lay down for more than $70 \%$ on 1 side. Four cows avoided lying on the mastitic side, but 2 cows lay down the most on the mastitic side. Cyples et al. (2012) also found no differences in the proportion of lying on the infected quarter between the baseline and LPS challenge day in mastitic cows (0.51 and 0.48 , respectively).

Overall, the laterality of lying down had a high variability between individuals. In agreement with the literature, our study reports approximately $47 \%$ of time 
lying on the right side for control cows (Forsberg et al., 2008; Tucker et al., 2009; Ledgerwood et al., 2010). Thus, to use lying laterality as an indicator of pain associated with mastitis, the individual lying side preferences of each cow must first be known to conclude with confidence whether an individual cow is experiencing pain based on changes in her lying side preference.

Usually, an increase in cow movements is associated with agitation during a stressful situation (Grandin, 1993, 1997), and behavioral signs of restlessness have been used to evaluate stress during milking (Rushen et al., 2001). The present study found a higher frequency of kicking, lifting, and stepping during milking during the first $3 \mathrm{~d}$ after mastitis detection, which might be due to the presence of mastitis. Gygax et al. (2008) also found that cows with high SCC had a higher rate of stepping during milking. The findings of the present study are consistent with results of other studies that have found increased restlessness behaviors in cows experiencing stress or pain (Peters et al., 2010; Chapinal et al., 2011).

In experiment 1 , mastitic cows shifted weight more often (shown by the SD of weight applied to the legs) on days when mastitis was present compared with after treatment (d 10+). Previous research showed more weight shifting by cows because of other painful conditions, such as lameness or uncomfortable flooring (Neveux et al., 2006; Rushen et al., 2007). However, the same pattern of results was seen in the control cows. Because it was not possible to familiarize the cows with the weigh scale, as was done in other studies (Chapinal et al., 2009, 2010a,b; Pastell et al., 2010), the change in time might have resulted from cows habituating to the weigh scale. Additionally, the percentage of weight applied to the leg on the mastitic quarter did not differ between mastitic and control cows. This result was opposite the one expected based on the results of some studies on lameness and uncomfortable surfaces in which cows applied less weight on the injured leg (Rushen et al., 2007) or on the leg placed on the uncomfortable surface (Neveux et al., 2006). However, this result could be related to the severity of the mastitis in our cows, in which the lack of swelling and heat in the udder did not cause a painful sensation that could affect the distribution of weight at the moment of standing.

The hock-to-hock distance is a measure of hind leg stance, which has been reported to be wider in mastitic cows because of the inflammation present in the udder at the onset of a mastitis infection (Kemp et al., 2008). However, in our study the hock-to-hock distance did not differ between control and mastitic cows, and no reduction in hock-to-hock distance was found after treatment $(\mathrm{d} 10+)$.
Environmental pathogens were the most common microorganisms isolated, supporting previous studies (Sargeant et al., 1998; Olde Riekerink et al., 2008). Zdanowicz et al. (2004) found that streptococci were more commonly isolated from teat ends of sand-bedded cows compared with sawdust-bedded cows; therefore, the isolation in milk of E. faecium was expected to occur. Although the isolation from teat ends of $E$. coli and $K$. oxytoca (coliforms) has been the most related to sawdust bedding (Zdanowicz et al., 2004), they were isolated from milk in 2 and 3 cows, respectively. We obtained 4 cases of no bacteria growth, which is in agreement with previous studies (Sargeant et al., 1998; Olde Riekerink et al., 2008). Culture-negative results might be attributed to either Escherichia coli (Schukken et al., 1989; Zorah et al., 1993) or staphylococci (Taponen et al., 2009).

\section{CONCLUSIONS}

With the methodologies proposed in this study, cows with mild clinical mastitis showed reduced lying time and increased activity and restless behaviors during milking compared with healthy cows, which could be due to consequences of mastitis. Furthermore, they showed some slight differences in laterality of lying and weight distribution. However, these responses could not be interpreted as pain-specific responses because of the limitations (lack of knowledge of lying side preferences and habituation period) that we faced with recording these measures. To develop methodologies for assessing pain associated with mastitis, it is worth applying the behavioral measures used in this study in cows with moderate to severe mastitis. Following this, validation of the methodologies using analgesic treatment to confirm that the responses are specific-pain behaviors is needed.

\section{ACKNOWLEDGMENTS}

We thank Jean-Phillip Parent, Gosia Zdanowicz, Ruby Wong, Jason Beukens, Nelson Dinn, and the staff of the University of British Columbia Dairy Research Centre (Agassiz, BC, Canada). The project was supported by Agriculture and Agri-Food Canada (Ottawa, ON, Canada) and the Natural Science and Engineering Research Council of Canada (Ottawa, ON, Canada). We thank Ken Leslie (University of Guelph, Guelph, ON, Canada) for his helpful insights.

\section{REFERENCES}

Cavallina, R., C. Roncoroni, M. C. Campagna, M. Minero, and E. Canali. 2006. Buffalo behavioral response to machine milking in early lactation. Ital. J. Anim. Sci. 7:287-296. 
Chapinal, N., A. M. de Passillé, and J. Rushen. 2009. Weight distribution and gait in dairy cattle are affected by milking and late pregnancy. J. Dairy Sci. 92:581-588.

Chapinal, N., A. M. de Passillé, J. Rushen, and C. B. Tucker. 2011. Short communication: Measures of weight distribution and frequency of steps as indicators of restless behavior. J. Dairy Sci. 94:800-803.

Chapinal, N., A. M. de Passillé, J. Rushen, and S. A. Wagner. 2010a. Automated methods of detecting lameness and measuring analgesia in dairy cattle. J. Dairy Sci. 93:2007-2013.

Chapinal, N., A. M. de Passillé, J. Rushen, and S. A. Wagner. 2010b. Effect of analgesia during hoof trimming on gait, weight distribution, and activity of dairy cattle. J. Dairy Sci. 93:3039-3046.

Cyples, J. A., C. E. Fitzpatrick, K. E. Leslie, T. J. DeVries, D. B. Haley, and N. Chapinal. 2012. Short communication: The effects of experimentally induced Escherichia coli clinical mastitis on lying behavior of dairy cows. J. Dairy Sci. 95:2571-2575.

Eckersall, P. D., F. J. Young, C. McComb, C. J. Hogarth, A. Weber, T. McDonald, A. M. Nolan, and J. L. Fitzpatrick. 2001. Acute phase proteins in serum and milk from dairy cows with clinical mastitis. Vet. Rec. 148:35-41.

EFSA (European Food Safety Authority). 2011. Scientific Opinion on the Use of Animal-Based Measures to Assess the Welfare of Dairy Cows. Eur. Food Saf. Auth., Parma, Italy.

Fitzpatrick, C. E., N. Chapinal, T. F. Duffield, D. F. Kelton, T. J. DeVries, C. Petersson-Wolfe, and K. L. Leslie. 2011. Objective assessment of pain in dairy cattle with clinical mastitis. Abstr. 43 page 79 in Research Symposium, University of Guelph, Guelph, ON. Canada. Campbell Centre for the Study of Animal Welfare, University of Guelph, Guelph, ON, Canada

Fitzpatrick, J. L., F. J. Young, D. Eckersall, D. N. Logue, C. H Knight, and A. Nolan. 1999. Mastitis-A painful problem? Brit. Cattle Vet. Assoc. 7:225-226.

Flower, F. C., and D. M. Weary. 2006. Effect of hoof pathologies on subjective assessments of dairy cow gait. J. Dairy Sci. 89:139-146.

Forsberg, A. M., G. Petterson, T. Ljungberg, and K. SvennerstenSjaunja. 2008. A brief note about cow lying behavior-Do cows choose left and right lying side equally? Appl. Anim. Behav. Sci. $114: 32-36$

Gibbons, J., C. Medrano-Galarza, A. M. de Passillé, and J. Rushen. 2012. Lying laterality and the effect of IceTag data loggers on lying behaviour of dairy cows. Appl. Anim. Behav. Sci. 136:104-107.

Grandin, T. 1993. Behavioral agitation during handling of cattle is persistent over time. Appl. Anim. Behav. Sci. 36:1-9.

Grandin, T. 1997. Assessment of stress during handling and transport. J. Anim. Sci. 75:249-257.

Gygax, L., I. Neuffer, C. Kaufmann, R. Hauser, and B. Wechsler. 2008. Restlessness behaviour, heart rate and heart-rate variability of dairy cows milked in two types of automatic milking systems and auto-tandem milking parlours. Appl. Anim. Behav. Sci. 109:167-179

Hänninen, L., and M. Pastell. 2009. CowLog: Open source software for coding behaviors from digital video. Behav. Res. Methods 41:472-476.

Hassall, S. A., W. R. Ward, and R. D. Murray. 1993. Effects of lameness on the behavior of cows during summer. Vet. Rec. 132:578580

Hogan, J. S., K. L. Smith, K. H. Hoblet, P. S. Schoenberger, D. A. Todhunter, W. D. Hueston, D. E. Pritchard, G. L. Bowman, L. E. Heider, B. L. Brockett, and H. R. Conrad. 1989. Field survey of clinical mastitis in low somatic cell count herds. J. Dairy Sci. 72:1547-1556

Ito, K., D. M. Weary, and M. A. G. von Keyserlingk. 2009. Lying behavior: Assessing within- and between-herd variation in free-stallhoused dairy cows. J. Dairy Sci. 92:4412-4420.

Kemp, M. H., A. M. Nolan, P. J. Cripps, and J. L. Fitzpatrick. 2008. Animal-based measurements of the severity of mastitis in dairy cows. Vet. Rec. 163:175-179.
Ledgerwood, D. N., C. Winckler, and C. B. Tucker. 2010. Evaluation of data loggers, sampling intervals, and editing techniques for measuring the lying behavior of dairy cattle. J. Dairy Sci. 93:5129-5139.

Neveux, S., D. M. Weary, J. Rushen, M. A. G. von Keyserlingk, and A. M. de Passillé. 2006. Hoof discomfort changes how dairy cattle distribute their body weight. J. Dairy Sci. 89:2503-2509.

O'Driscoll, K., L. Boyle, and A. Hanlon. 2008. A brief note on the validation of a system for recording lying behaviour in dairy cows. Appl. Anim. Behav. Sci. 111:195-200.

Olde Riekerink, R. G. M., H. W. Barkema, D. F. Kelton, and D. T. Scholl. 2008. Incidence rate of clinical mastitis on Canadian dairy farms. J. Dairy Sci. 91:1366-1377.

Pastell, M., L. Hänninen, A. M. de Passillé, and J. Rushen. 2010. Measures of weight distribution of dairy cows to detect lameness and the presence of hoof lesions. J. Dairy Sci. 93:954-960.

Peters, M. D. P., I. D. Silveira-Barbosa, L. C. Pinheiro-Machado-Filho, A. A. Machado, and L. M. R. Pereira. 2010. Manejo aversivo em bovinos leiteiros e efeitos no bem-estar, comportamento e aspectos produtivos. Arch. Zootec. 59:435-442.

Rousing, T., M. Bonde, J. H. Badsberg, and J. T. Sørensen. 2004 Stepping and kicking behavior during milking in relation to response in human-animal interaction test and clinical health in loose housed dairy cows. Livest. Prod. Sci. 88:1-8.

Rushen, J., L. Munksgaard, P. G. Marnet, and A. M. de Passillé. 2001. Human contact and the effects of acute stress on cows at milking. Appl. Anim. Behav. Sci. 73:1-14.

Rushen, J., E. Pombourcq, and A. M. de Passillé. 2007. Validation of two measures of lameness in dairy cows. Appl. Anim. Behav. Sci. 106:173-177.

Sargeant, J. M., H. M. Scott, K. E. Leslie, M. J. Ireland, and A. Bashiri. 1998. Clinical mastitis in dairy cattle in Ontario: Frequency of occurrence and bacteriological isolates. Can. Vet. J. 39:33-38.

SAS Institute. 2008. SAS User's Guide. SAS Inst. Inc., Cary, NC.

Schukken, Y. H., J. A. H. Smit, F. J. Grommers, D. Vandegeer, and A. Brand. 1989. Effects of freezing on bacteriologic culturing of mastitis milk samples. J. Dairy Sci. 72:1900-1906.

Siivonen, J., S. Taponen, M. Hovinen, M. Pastell, B. J. Lensink, S. Pyörälä, and L. Hänninen. 2011. Impact of acute clinical mastitis on cow behaviour. Appl. Anim. Behav. Sci. 132:101-106.

Smith, B. P. 2009. Large Animal Internal Medicine. 4th ed. Mosby Elsevier, St. Louis, MO.

Taponen, S., L. Salmikivi, H. Simojoki, M. T. Koskinen, and S. Pyörälä. 2009. Real-time polymerase chain reaction-based identification of bacteria in milk samples from bovine clinical mastitis with no growth in conventional culturing. J. Dairy Sci. 92:26102617.

Tucker, C. B., N. R. Cox, D. M. Weary, and M. Špinka. 2009. Laterality of lying behaviour in dairy cattle. Appl. Anim. Behav. Sci. 120:125-131.

Viguier, C., S. Arora, N. Gilmartin, K. Welbeck, and R. O'Kennedy. 2009. Mastitis detection: Current trends and future perspectives. Trends Biotechnol. 27:486-493.

Wagner, S. A., and M. D. Apley. 2004. Effects of two anti-inflammatory drugs on physiologic variables and milk production in cows with endotoxin-induced mastitis. Am. J. Vet. Res. 65:64-68.

Zdanowicz, M., J. A. Shelford, C. B. Tucker, D. M. Weary, and M. A. G. von Keyserlingk. 2004. Bacterial populations on teat ends of dairy cows housed in free stalls and bedded with either sand or sawdust. J. Dairy Sci. 87:1694-1701.

Zorah, K. T., R. C. Daniel, and A. J. Frost. 1993. Detection of bacterial antigens in milk samples from clinical cases of bovine mastitis in which culture is negative. Vet. Rec. 132:208-210. 